
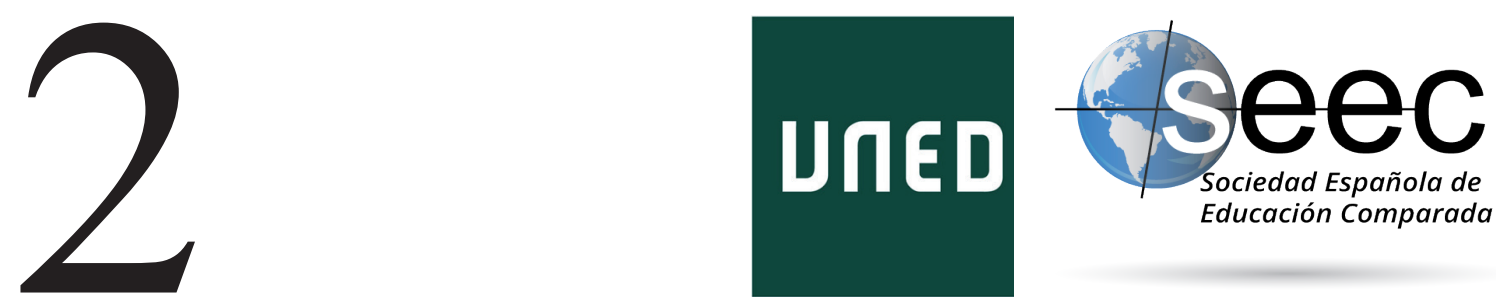

\title{
Tracking Three Traditions in the Historiography of Education Toward Comparative Methods
}

Hacia un comparatismo Post-Ilustrado: tradiciones y perspectivas en la historiografía de la educación

\section{Cristiano Casalini*; Laura Madella**}

DoI: $10.5944 /$ reec.34.2019.24321

\section{Recibido: 27 de abril de 2019 Aceptado: 27 de junio de 2019}

\footnotetext{
*CRistiano CASALINI: Profesor Asociado en el Departamento de Educación del Profesorado, Educación Especial y Currículo e Instrucción en el Boston College de los EE.UU. Es un experto en pedagogía jesuítica e Historia de la Educación. Es un investigador del Instituto para Estudios Jesuíticos Avanzados. Enseña historia de la pedagogía jesuítica, justicia social en contextos jesuíticos, y filosofía de la educación. Sus publicaciones incluyen obras como 'The jesuit Philosophy on the Era of Modernity' (Brill, Leiden, 2019), y 'Benet Perera and Early Jesuit Pedagogy' (Anicia, Rome, 2016). Datos de contacto: E-mail: casalini@bc.edu

**Laura Madella: Profesora e Investigadora del Dipartimento di Discipline Umanistiche Sociali e delle Imprese Culturali de la Universidad de Parma. Entre sus numerosas obras destacan publicaciones como "Sull'Alphabeto christiano di juan de Valdés" (Edizioni Anicia, 2018), y "Immured in monasteries. L'immagine dell'Europa negli schoolbook di Washington Irving”. Datos de contacto: E-mail: laura. madella@unipr.it
} 


\begin{abstract}
From the epistemological point of view, the field of history of education has always been one of the most challenging for scholarship to define. The roots of such a difficulty are multilayered and have barely emerged over time, but they have kept their grasp on the potential development of a field that could make an enormous contribution to the global understanding of one of the core practices of every human society. In this chapter, we will dig into these roots, cutting across epistemological and geo-cultural perspectives, in order to provide a scenario that might overcome the impasse that impedes the global recognition of the scholarly and academic field of the history of education, and put forward a tentative outline of an approach that could pave the way for such recognition. This approach is based on the comparative method. It is not anything new, as it dwells in the Enlightened attitude toward universalism and comparativism for global literature, historiography, philosophy, and so on. But it has paradoxically found very few chances so far to be applied in the literature of the history of education. This chapter will inquire into the reasons for this neglect, and outline an epistemology of a comparative method that might illustrate new ways of thinking about production for the future of the history of education.
\end{abstract}

Key Words: epistemology; History of Education; comparative method; universalism; comparatism

\title{
Resumen
}

Desde un prisma epistemológico, el ámbito de la Historia de la Educación siempre se ha revelado uno de los más complejos de definir desde una perspectiva académica. Las raíces de dicha dificultad son múltiples y han emergido a lo largo del tiempo, pero se han fundamentado en el desarrollo potencial de un ámbito que podría realizar una enorme contribución a la comprensión global de una de las prácticas nucleares de toda sociedad humana. En este capítulo profundizamos en estas raíces, incidiendo en perspectivas epistemológicas y geo-culturales, con vistas a proporcionar un escenario que podría superar el impasse que impide el reconocimiento global del ámbito escolar y académico de la historia de la educación, y avanzara en el diseño tentativo de un enfoque que podría cimentar el camino a dicho reconocimiento. Este enfoque está basado en el método comparado. No es algo nuevo, como se desprende de la actitud ilustrada hacia el universalismo y el comparatismo en relación a la literatura global, historiografía, filosofía y otros. Pero, de forma paradójica, hasta la fecha ha encontrado muy pocas oportunidades de ser aplicado en la literatura de la Historia de la Educación. Este artículo indagará en los rasgos de esta negligencia, y esbozará una epistemología de un método comparado que puede ilustrar nuevos caminos de pensamiento en relación a la producción para el futuro de la Historia de la Educación.

Palabras clave: epistemología; Historia de la Educación; método comparado; universalismo; comparatismo 


\section{Introduction}

From the epistemological point of view, the field of the History of education has always been one of the most challenging for scholarship to define. Is it a branch of history? Is it an historical inquiry about theories and practices of education? Does it serve theoretical, practical or political purposes? Is it about ideas, facts, models, mentalities? Questions like these have marked the developments of History of education as an academic discipline since its very beginnings, which can be arguably identified in the nineteenth-century discussions about the structures of universities and the epistemological discourses performed within and sprouting from academe.

Rooted in a century of nation states and in a time characterized by a strongly disciplinary mainstream mentality (which included a focus on the status and legitimacy of human/social sciences), the History of education has not surprisingly developed different traditions in different countries, for the cultural debate in each country had begun with and focused on differently perceived principles and methods. For example, Education theory developed as an independent, "scientific" discourse in German lands; the History of education developed in service of this discourse insofar as its goal was to employ historical examples to assess in a helpful way the effectiveness of pedagogies and educational models. In other countries, the theory of education remained a "minor" division of philosophy, and so the field of History of education remained split into two parts: on the one hand, a history of ideas, given mostly to philosophers' discussion and criticism; and on the other, a history of facts, offering either policies of education to be discussed with reference to historiographical sources, or institutional narratives that were not intended to transform contemporary educational practices. In countries where epistemological ruptures affected major disciplines, such as General history in France, the History of education was eventually and heavily affected in topics, methods, and choices of professional authorities. This meant that general historians, largely inclined toward inquiries into social issues, inevitably developed a great interest in the social phenomenon of education. They produced a vast literature in the field, even as historians of education went on dealing with ideas and only later coming to embrace the social history of education.

Despite the different origins and early developments of national traditions in the academic field of the History of education, a review of the most recent literature shows that comparative methods and topics have been attracting the general attention of the historians of education worldwide.

In this article, we will track three major historiographical traditions (Germany, France, and the United States), which might be taken into account as examples of howfrom different backgrounds, sometimes even from opposite epistemic options-they all developed in the direction of a contemporary comparative method, thus enriching the scope and perspectives of a global scholarly engagement with the history of education.

\section{German Historiography of Education}

Rather than on the "History of Education", the German-speaking tradition has preferred to focus on the "History of Pedagogy" (Geschichte der Pädagogik) until the 1970s. The majority of works in this tradition generally privileged a chronological exposition of the theories and lives of the main educators, or the history, organizations and outcomes of 
the main institutions, rather than a display of educational practices or policies through time. In German lands, such a kind of historical representation had spread since the mid-18th century, ${ }^{1}$ boosted by the expectation of educational reforms as put forward by the Enlightened policies.

The history of pedagogy saw the first attempts at systematization before the philosophy of education, since Kant's Über Pädagogik dates back to 1803 and Herbart's Allgemeine Pädagogik to 1806.

According to Jürgen Oelkers, pedagogical historiography began to take shape as a genre in itself at the outset of the 19th century, when general historiography kept reflecting on the time-frame meaning of its works and the necessity to historicize itself (Oelkers, 1999, p. 462). For the historiography of pedagogy, this meant pursuing a pedagogical purpose, displaying the past to teach something useful for the contemporary educational practices. But its 18th century roots might have bequeathed some features which had informed pedagogical historiography for more than a century, contributing to keeping alive some peculiarly German inconsistencies: although German-speaking lands, in particular the Kingdom of Prussia, had since late modern history had the highest number of academic chairs of education, these often remained dependent on another "major" discipline, mainly philosophy; ${ }^{2}$ moreover, while the authors of works on philosophy or theory of education were generally theoretical scholars and academic professors, the histories of pedagogy were mostly written by educators, teachers, school directors and by people involved in some capacity in educational or scholastic organizations, who, in addition, were also theoretical scholars and sometimes academic professors. ${ }^{3}$

First, pedagogical historiography had a Christian teleological identity. German scholars considered the history of pedagogy as a continuum, a unique Christian route whose main landmark was the Lutheran Reform, and clearly bore in mind that one aspect of the Lutheran mission, assigned by God's will, was the instruction of the German people (nation). ${ }^{4}$ In this way, not only did the function of teachers acquire a demanding role, but much more so did the function of those who were to provide and organize their teaching.

Second, recent studies on the social and cultural roots of German modernity and citizenship (Hull, 1996; Anderson, 2000; McNeely, 2003; Penny, 2008) put into the foreground the role that cameralists, bureaucrats and "state employers" played during the period that Reinhart Koselleck named Sattelzeit (Koselleck, 1972, p. xv),5 stating that

1 At the outset of the century they were mostly written in Latin (Schöttgens, 1717; Keuffel, 1743) and then German prevailed (Biedermann, 1752; Ruhkopf, 1794).

2 The first chair of Pedagogy had been established in 1779 at the University of Halle and held by Ernst Christian Trapp, but it was officially a chair of "Philosophy and Pedagogy", as well as the chairs of Herbart, Paulsen, Dilthey. According to Ulrich Herrmann, in 1907 there were in Germany only five full professorships of Pedagogy, in Jena, Prague, Frankfurt and two in Munich (Handbuch der deutschen Bildungsgeschichte, IV, p. 160).

3 Friedrich E. Ruhkopf, Friedrich H. C. Schwarz, Adolph Diesterweg, Friederich Cramer, Karl Schmidt, Karl von Raumer, Karl Adolf Schmid, Wilhelm Braubach, Carl Kehr..

4 Meaningfully, Luther dealt with the topic of school education for the first time in the discourse To the Christian Nobility of the German Nation (1520). The Letter to the Mayors and Alderman of the Cities of Germany on Behalf of Christian Schools (1524) and A Sermon on the Duty of Parents to send their Children to School (1530) did follow.

5 Referring to German history, Reinhart Koselleck named Sattelzeit (saddle-age) the period from 1750 to 1850, reading it as a long transition from the Early Modern (die frühe Neuzeit) to the Late Modern History (die Moderne). The concept arose in the field of Bielenfeld's social studies and conceptual history and, along with them, underwent some criticisms, which nevertheless do not prevent many scholars from keeping adopting it, especially while dealing with political and social history of that age. 
the proposals for reforms, in all fields, often came from the ranks of lower officials in the form of handbooks. ${ }^{6}$

Maybe this helps to explain the reason why a great part of German pedagogical historiography before WW1 was addressed to and written by professional figures from educative institutions, and why the authorities in charge of academic management perceived the discipline as a mere tool of teacher information, preparatory to a specific teaching subject that was not specifically pedagogic.

After the 1848 (non-German) revolutions and mostly after the birth of the German Empire (1871), the State took advantage of its nation's predisposition to bolster those kinds of pedagogical histories that best suited its political goals, but at the same time it gradually deprived its people of the initiative and responsibility that had typified them during the Enlightenment and the first decades of the century (Groppe, 2012, pp. 183-84). The history of pedagogy was needed to train prospective teachers, in particular for primary schools, so a host of "historical handbooks" were officially approved as textbooks: they had, of course, a "dogmatic" layout, displayed authors and institutions chronologically, and gave German personalities a hegemonic role-though avoiding allowing them any greater prominence than German institutions. Consequently, these books became bestsellers, and some of them were reprinted until the 1920s (Tröhler, 2006, p. 544-46). ${ }^{7}$

The most impressive historiographic event of the century, and the strongest in its assertion that pedagogy sprouted out from the cultural spirit to the Nation before any other institution or entity, was the edition of the Monumenta Germaniae Paedagogica. ${ }^{8}$ This collection followed the paradigm of the Monumenta Germaniae Historica and published 62 volumes from 1886 to 1938 (thus, continuing under Nazism), bringing together a wide range of educational sources (school-rules, theoretical treatises, biographies and bibliographies, historical inquiries, didactics of music and the arts, military education...). Sources about Protestant education were prevalent, even though 4 volumes were devoted to the whole history and evolution of the Jesuit Ratio studiorum in the German Province. From 1886 until 1905, the editor of the project was Karl Kehrbach (1846-1905), a scholar, librarian, teacher and school director.

The 19th century also produced an amount of pedagogical historiography that was not officially approved, at least not for prospective school teachers, but nevertheless anticipated future tendencies and exerted an influence on European and American studies. Some authors showed in their histories a cultural perspective. Friedrich H. C. Schwarz's Geschichte der Erziehung (1813) starts from an enlightened comparativism to display pedagogical history as a part of the cultural history of mankind; and later Karl

6 "The church set the legal standards, society established its norms, and the state was unable to dominate society in any absolute way during the age of absolutism. Reforms happened, and when legal reform came to state and society, it was often not from on high or, as many scholars might hope or assume, in the wake of pressure from enlightened public opinion. Rather, "state officials, often beginning at its lowest judicial levels”, struggled for change” (Penny, 2008, p. 85).

7 In particular Josef Kehrein, Überblick der Geschichte der Erziehung und des Unterrichts: für Zöglinge der Lehrerseminare und zur Vorbereitung auf die Allgemeine Bestimmungen angeordneten Prüfungen (Paderborn, 1873) and August Schorn, Geschichte der Pädagogik, in Vorbildern und Bildern (Leipzig, 1873).

8 "The Monumenta will offer, for the first time, the foundation of the history of global teaching and education in the German-speaking lands (...) They shall present the global development of German education and teaching in its essential literary outcomes, without any preference for any specific genre, period or confession, and above all without any partial point of view" (Kehrbach, 1886, 6). 
Schmidt theorized that pedagogy should be an application of anthropology (Geschichte der Pädagogik dargestellt in weltgeschichtlicher Entwicklung und im Organischen Zusammenhang mit dem Kulturleben, 1860). There were liberal thinkers such as Adolph Diesterweg, teacher and school director, who focused on the "historical present" and the evolution of didactical practices; and scholars against the dogmatic layout of the mainstream like Friedrich von Raumer (also a teacher and school director), according to whose Geschichte der Pädagogik (4 volumes 1842 to 1854) the only aspect of continuity in it was the persistence of a Bildungsideal, an "ideal of formation" differently represented in each age and generation, and particularly emblematic in some remarkable individuals who were not necessarily education theorists. In the late 19th century, Diesterweg and Von Raumer were among the authors most frequently mentioned and quoted by the American educational press, not to mention the books of Friedrich Paulsen, pioneering the empirical research into the history of education with his Geschichte der gelehrten Unterrichts auf den deutschen Schulen und Universitäten (1885).

When WW1 erupted, German theories on historical education were an inspiration for many American historiographies of education, but, for political reasons, scholars would abruptly disavow them (Fallace, 2017, p. 3).

The idea of pedagogy as a scientific, independent discipline emerged in Germany during the Weimar Republic, with the double function of training teachers and "accompanying and leading the way for social and political change" (Groppe, 2012, p. 182). "Scientific" did not mean "empirical"; rather the terms "practical", turning into "humanistic", revolved around the subject. The historical thought on humanistic pedagogy shifted dramatically from the bold experiments of Weimar to a partial consent to Nazism. This is well represented by the work of Herman Nohl, Die Deutsche Bewegung und ihre Theorie (1921-1939), which connects the German "pedagogical movement" (Bewegung) in 1933-35 with the pre-unitarian artistic and intellectual movement (1770-1830). Nohl justified the shift this way: the urban, industrial, and material development of the 19th century distracted Germans from their authentic desire and inclination toward the unity of a cultural identity (a Sonderweg-identity, solely German, the one to distinguish Germans from non-Germans), and the period from the end of the war to the Weimar Republic abandoned them to a sense of alienation (Groppe, 2012, 184). Contemporary historians found another possible connection: in Germany, historicism, which in America had promptly been politically connected to democracy, had developed among scholars on a monarchical basis. It was such a monarchical tradition that historians lost after WW1, and not the dream of a cultural unity (Depkat, 2009, p. 431).

Browsing the publications of historical pedagogy from 1939 to 1945, one finds books on historical "volkhafte Bildung", "volkhaft" being a specific adjective of the Third Reich period to mean "national, of the people" (Kemplerer, 2006, p. 248), used by authors who had already written on educational history during the Republic (for instance, Friedrich Glaeser), various histories of pedagogy during the Enlightenment (written by the Swiss Leo Weber), and the History of Pedagogy written in 1907 by the German psychologist Hermann Weimer. There were many concessions to prosaic handbooks of popular education, and also many reprints of older works offering a linear history in which German theories stood out as the best in the world.

After 1945, West Germany woke up to the bitter awareness that its pedagogical historiography did not have, and thus could not have, any pedagogical effect. For a while, histories of pedagogy were still linear and humanistic, until the influence of the social 
studies helped historical pedagogy to unfold a critique of Germany's national history and the historicist tradition. Its purpose could only be related to knowledge (Tröhler, 2006, p. 552), a knowledge that was also concerned with the identity of the discipline and its scholars. In this field was published the collective and ponderous work Handbuch der Deutschen Bildungsgeschichte (1st volume 1987), a first comprehensive overview of the History of Education "recognized by and connected with its related disciplines of history and sociology", and in this field the "History of Pedagogy" updated its lexicon and evolved into the "History of Education" and "historische Bildungsforschung", "historical research on Education” (Groppe, 2012, p. 186).

Only after the 1980 s did scholars from inside the field of social history begin to criticize their very school (Lüdtke, 1991; Medick, 1996) and claimed the necessity "to embrace anthropology, phenomenology, post-structuralism and other theories from the field of cultural studies as a means to 'complete' and 'fulfill' the social history project" (Depkat, 2009, p. 433). In this case, outstanding inputs toward comparativism came to the German Studies from the American academies, notably through the works of Fritz Ringer (Ringer , 1978 and 1992). ${ }^{9}$

The plea of the social history also strove to converge historiography with the empirical research that had interested social studies since the postwar period. Emblematic in this way was the unfolding of the German Institute of Educational Research (DIPF, today Leibniz Institut für Bildungsforschung und Bildungsinformation): created in 1951 for the development of empirical educational research, its activities gradually embraced a comparative overview and displayed a clear will to historically ground their raison d'être. Those directions acquired a stronger meaning and new goals after 1989, and in 1990, within the Institute in Berlin, the Library for Research on Educational History was created (BBF); today it is the biggest German library specializing in educational history. Since 2012 the Leibniz Institute has hosted a professorship for Research in History of Education, and a History of Education department. Inside the DIPF, during the 1970s the research of Christoph Wulf on the anthropology of education began, which later gave birth to authoritative works from a historical perspective (Wulf, 1996 and 1999).

Looking at the recent debates on histories and the historiography of education, one can tell that anthropology acted as a mediator to address educational historiography toward a frame of reference suited for today's globalized world, thus not merely cultural but, rather, intercultural (Gogolin, 2002; Krüger-Portraz, 2005; Eigenmann, 2018). As well as viewing politics as basically the cause of the human movements that today make the demand for intercultural knowledge and "skills" more pressing and challenging, recent authors are putting politics at the center of their premises and conclusions on the cultural historiography of educational issues (Fuchs, 2005 and 2013; Fend, 2006), taking the risk to retrieve for it that pedagogical purpose which, so far, has been impossible to achieve.

9 Fritz K. Ringer (1934-2006) was born in Germany but had moved to US shortly after the end of WW2. His comparative research in social and intellectual history of Europe originated from a deep inquiry into the German educational system during the Empire of Wilhelm II and the Weimar Republic (Ringer 1969). 


\section{French Historiography of Education}

The modern development of the historiography of education in France began with what has been labeled as a "chauvinist" disengagement from Educational Theory, a discipline that indeed had been established in Germany. In 1857, in the midst of the years when Prussia had begun a political and military reorganization that would eventually culminate in the Franco-Prussian war, Théodore Barrau, the director of the official journal of the French Ministry of Education, addressed a not-so-friendly welcome to the 'newlyestablished' discipline of History of Education: "There exist a number of laboriously useless sciences; among these one finds the history of education and learning, which emerged in the early nineteenth century" (Barrau, 1857, pp. $4-5) .^{10}$

Barrau did not mention explicitly the German origins of such a doctrine, but his further epistemological remarks made it clear that the French attitude to this history of education was totally different from that of Germany. He said that the history of education as such could not exist beyond the field of general history, and if its purpose was to illustrate and perfect current practices and pedagogies, the history of education was useless.

As we saw above, the German model was different, and saw the history of education basically as a pedagogic research conducted within an historical frame. The assumption of such a model was that the history of education was meant to provide instruments and tools to ameliorate and improve the current educational system and practices. For this purpose, the main focus of the history of education was seen as addressing the educational theories of the past, as well as the logical relations between models of educational policies and those theories that had inspired them. It was to this goal that the activities of the scientific Society for Educational History, founded in 1890, were explicitly devoted. The Monumenta Germaniae Paedagogica (62 volumes in total) was the outstanding and titanic product of such an endeavor.

Of course, the political and theoretical nature of the educational models was not foreign in France, especially in the last quarter of the nineteenth century. ${ }^{11}$ But the contributions and the debate there were rather constrained by the ideological dialectic between Catholics and republicans on the role of the church as the educator of the French people in the early modern period. Among the most eminent examples of such historiographers were Gabriel Compayré (1843-1913) and Ferdinand Buisson (1841-1932). ${ }^{12}$

Nonetheless, the dependence of the historiography of education on epistemic models that were drawn from other disciplines in the humanities was powerfully reaffirmed with the appointment at the Sorbonne of Émile Durkheim as chair of the history of teaching in 1904. The impact of this event on the field was strengthened by two basic facts: 1)

10 The article was reprinted in Histoire de l'education 30 (may, 1986): 67-71. We quote the translation from Caspard \& Rogers, 2012, p. 73.

11 Herbart's works circulated in French translations and, indirectly and years before, through the activities of and writings by the Swiss Franciscan Jean-Baptiste Girard (1765-1850). See Guex, 1892.

12 Both directly involved in French politics. Compayré served the Union Républicaine in the National Assembly while teaching philosophy at the University of Toulouse, his most outstanding work was the Histoire de la Pédagogie (1883). The broad-spectrum writings of the Nobel Peace Prize Ferdinand Bouillon (Dictionnaire de pédagogie et d'instruction primaire; Répertoire des ouvrages pédagogiques du XVIe siècle; L'enseignement primaire supérieur et professionnel en France; L'instruction primaire en France de 1789 à 1889...) included also a comparative perspective, developed through Buisson's participation to the World Expo in Wien, Philadelphia and New Orleans, whereupon he committed to paper three Rapports sur l'instruction primaire à l'exposition universelle (1875, 1876 and 1878). 
the course Durkheim was to deliver originated as the result of a course in Pedagogy for secondary education teachers that a rule of 1902 introduced as mandatory for the aggregation of candidates to teaching; and 2) Durkheim's sociological background established an imprint that the successive French historiographers of education would have very seldom dismissed.

The first fact put the role of the historiography of education in direct connection with the goal of being "useful" for the professional practices of teachers. Such usefulness could be envisioned in a variety of ways, but criticisms were raised about this claim. Durkheim criticized "the old French prejudice" that looked contemptuously at the whole field of educational theory (Durkheim, 1969, p. 4), and opposed to the "neophiles" the belief in the history of education as a discipline that was able "to anticipate the future and to understand the present" (p. 9).

But how could the history of education be carried out in order to meet such practical expectations? For Durkheim - and here we refer to the second fact mentioned above-the crucial point is that "there is no field of action in which science, theory, that is to say reflection, does not increasingly explore and illuminate practice” (p. 4). As a social action, education and the reflection about education have been materialized in a variety of ways over time, so the main goal of a history of education is to find the interaction between the eternally changing flux of educational reflections and "the condition of society at the relevant moment” (p. 9) that stands as the single fixed and determining reference point of all such changes.

In other words, "no educational subject can be truly understood except by placing it in the context of the institutional development, the evolutionary process of which it forms a part, but of which it is only the contemporary and provisional culmination" (p. 11).

While praising the epistemic relevance of the history of education for the elaboration of a performative theory of education that could result in effective educational practice, Durkheim was in fact undermining the autonomy of that discipline, reclaiming for social sciences the leading role in writing histories of education. "Historical and social studiesDurkheim predicted-are close relatives and they are destined eventually to merge with one another" (p. 331).

The fact that Durkheim's course was not published until 1938, that is, more than a third of a century later, and had a second edition only in 1969, induced Jean-Luc Le Cam to infer the irrelevance of the epistemological issue of the history of education in France for a very long time (Le Cam, 2013, p. 105). On the contrary, though, we argue that those two dates of publication are extremely important in understanding the relevance and nature of the French historiography of education within the larger epistemic context. Indeed, those dates basically corresponded with two rising tides in the history of French historiography, corresponding to the first and second generations of the School of the Annales, a movement that had a tremendous impact on fulfilling Durkheim's prophecy.

As the leading paradigm of general history turned toward the adoption of methods and topics drawn from or in strict connection with social sciences, so the potential subjects within the field of the history of education became extremely compelling for a general history that was turning its attention toward practices, mentalities, longues-durées. Certainly, while the subjects were indeed compelling, the discipline was not needed. And rather than having scholars cultivating a specialization and building an epistemic/academic framework for the history of education, the topics of such a field just migrated into the broader compact of general history. This would happen later also in Italy, where the 
debate brought some scholars to talk about an "expropriation" of the field (Cambi, 2005, pp. 85-93; Bellatalla, 2006, pp. 32-36; Granese, 2008, p. 12). ${ }^{13}$

When Durkheim's course appeared in its second edition, it was just two years after the first autonomous departments of education were created in French academia, but their growth was impaired by the fact that they were kept separate from the training of teachers (Le Cam, 2013, p. 107) A small number of historians of education were affiliated in such departments, while the traditionally centralizing administration in France began to create some space for research on the history of French education within the context of a ministerial initiative that culminated in 1977 with the incorporation of the "mission of the history of education" (Mission d'histoire de l'éducation) into the INRP (Institut National de Recherche Pédagogique). Under the direction of Pierre Caspard, the newly-named Service d'histoire de l'éducation (SHE) published the first issue of the journal Histoire de l'éducation in 1978, which has over time become the reference periodical publication for the history of education in France. ${ }^{14}$

As Le Cam points out, although these initiatives were created under the umbrella of educational sciences, the major role in the renaissance of studies in the history of education was played by French scholars with a solid background in general history, without any link to departments of education. ${ }^{15}$ But the leading paradigm that influenced the large majority of such historiographers-a fact that contributed to creating "a distinctive mark of the French school" (Le Cam, 2013, 109) -was deeply linked with the developments of sociological and cultural studies. This approach favored and boosted research on pedagogic practices, scholastic routines, mentalities, and aspects of educational longue durée that neither an event-based historiography nor a traditional history of ideas could grasp. In a sense, what Durkheim had foreseen as the core element of an historiography of education based on a sociological approach became the common trait of many of French histories between the 1970's and 1990's:
"We shall see in fact how in France, whereas everything has changed, whereas the political, economic and ethical system has been revolutionized, there has never- theless been something which has remained palpably immutable until quite re- cent times: this is the educational presuppositions and procedures of what has come to be called a classical education" (Durkheim, 1969, p. 6).

On the other hand, methods of social sciences were strongly implemented that focused on social and geographical data, thus fulfilling Durkheim's prediction about the convergence of historiography and social sciences in the name of statistics. It is important to note the peculiar impact in France of social geography, whose maps and approaches can be particularly seen in scholars such as Julia and Compère ${ }^{16}$ and in a most recent but highly

13 History of Education can be considered and studied also as a part of general history, but with no universal nor total claims.

14 The impact of Pierre Caspard on the history of history of education in France cannot be overestimated. His studies have systematically covered the field and reported the historical debate on methods and role of historiography of education for decades. See Pierre Caspard 1979, pp. 5-17; 1984, pp. 5-23; 1988, pp. 14-15; 1998, 101-123; 2000, pp. 73-87; and Caspard and Caplat, 1981, pp. 665-676.

15 Le Cam's list of such scholar includes Antoine Prost, Maurice Crubellier, Parul Gerbod, Dominique Julia, Roger Chartier, Marie-Madeleine Compère, Jean Quéniart, François Furet, Mona Ozouf, Françoise Mayeur, Jean-Noël Luc, and Pierre Caspard (see Le Cam, p. 108).

16 Marie-Madeleine Compère (1946-2007) and Dominique Julia (b. 1940) wrote together the voluminous repertoire Le colleges français: $16^{\circ}-18^{\circ}$ siècle (1984-1988). Besides, see M. M. Compère, 1986-89 and Julia, 1987. 
meaningful contribution to a meta-historiography of education by Vincent Alamercery, who surveyed thousands of entries recorded on a bibliographic database of the history of education, crossing topics and geographical data to provide a brilliant landscape on how the French historiography of education has lately developed (Alamercery, 2008). As for the conclusions of this survey, the discipline of the history of education in France reveals a twofold epistemic weakness, which Alamercery covers under the name of "hybridity". Indeed, he points out that the activities of French historiographers of education reveal a fundamental hybridity, which is both scientific and cultural:

\begin{abstract}
"As a scientific discipline, it participates in the mainstream of social, cultural and political history, and shares the paradigms. As a cultural activity, it affects both teachers who are interested in searching in a geographically situated past for benchmarks on the evolution of their profession and their public, and citizens of small, local or regional homelands, whose school constitutes the collective equipment most massively implanted and frequented, so the most important to memory" (Alamercery, 2008, p. 116).
\end{abstract}

Dependent on the methods and topics that are drawn from general history, the "province" of the history of education becomes even smaller if seen from a cultural point of view. The breadth of its usefulness and practicality becomes circumscribed to that of providing local resources for teachers or citizen belonging to little Heimaten. If compared to the monumental endeavor of the German historiographers of education in the nineteenth century, who projected educational theory in the past so as to illuminate the future of German education, the theoretical force of the French historiography of education seems to reside in the un-usefulness and in-actuality of its exercise.

Although not from a French scholar, Marc Depaepe's commandments to historians of education apply very well to the way the discipline has been commonly perceived in France:

"1. Thou shalt remember that the history of education is history; 2. Thou shalt write about the educational past; 3 . Thou shalt not fret excessively about presentism; 4. Thou shalt not write a history of the present, nor for the present" (Depaepe, 2010, p. 31).

\title{
4. American Historiography of Education
}

The history of the American historiography of education has been shaped by the dimension of the present. The assumption that history is written for the amelioration of current society is as much embedded among historiographers as it is among policymakers and the wider public. This was true as early as in the nineteenth century, the dawn of the American historiography of education, as it is still today.

Of course, not everybody has been so confident with the presentist assumption, and sometimes the scholarly debate in the United States has become so harsh as to use presentism as a label for charging scholars of opposing schools with a lack of objectivity, naiveté, distortions, and celebratory intents. At the same time, though, such accusations were often raised so as to endorse supposedly more effective visions of the ongoing practices in real American educational structures, in fact perpetuating the same assumption under a different Weltanschauung. 
For a young nation building anew both its structures and the narrative of its own identity, there is bound to be an attitude toward practicality that tends to project backward to moderately recent times the immediate causes of a present that has to be improved, as the nation keeps growing.

The history of the history of American education fits almost perfectly with this attitude, beginning with pioneers such as Ellwood Cubberley (1868-1941), who in the first decades of the twentieth century published a monumental work on the endeavor of the United States to educate its youth. In the preface of his most influential Public Education in the United States (1919) he clarified that illuminating the national rationale behind current practices in the training of its youth was the main goal of his research: "In particular, the author tried to catch the spirit of our educational development and to use the facts as a background upon which to paint the picture which our national evolution presents" (Cubberley, 1947, vii).

Cubberley's addressees were both new students, to whom to provide a connected story of the institutional developments of education in the context of the social, political, and industrial forces that shaped the United States during the nineteenth century, and American teachers "to see the educational problems of the twentieth century in the light of their historical developments" (p. vii). Cubberley's work was the first tentative systematization in the history of American education that tried to overcome the "encyclopedic" styles of his few predecessors, and shift the focus from Europe to America, from intellectual history to social history, and from the history of educational theories to the history of educational institutions (Cohen, 1976, p. 306; ). ${ }^{17}$

While Cubberley was not trained as an historian, Paul Monroe (1869-1947) -who shared the same vision on an institutional historiography and was brought at the turn of the century to Teachers College at Columbia University to teach the history of education-was. His early A Textbook in the History of Education (1905) became a standard in the field of the history of European Education, and, thanks to his position as editor of The Cyclopedia of Education (1912) and to his students-who would become the second generation of American historians of education-he had a profound impact on the leading paradigm in the field until the "40s, when his The Founding of the American Public School System (1940) appeared.

The 1930 and 1940 s saw the rise of progressive education in the United States, and social reconstructionism put a special emphasis on reforming education as the most important tool to build society beyond the failures of capitalism and the Great Depression. As John Dewey's philosophy of education successfully spread among academia/academies and increasingly shaped American schools, Dewey's students such as William Kilpatrick, Harold Rugg, and George Counts endeavored to elevate the figure of the "educationist" to the main character of the social reconstruction of the country. ${ }^{18}$ At the same time, the movement of progressive historians challenged the institutionalism and formal method of general historians that had influenced the American Historical Society since its beginnings, offering an engaged and bellicose vision of the historian as fundamentally social-oriented. As Cohen notes, progressive historians, like James Harvey Robinson, Frederick Jackson Turner, Vernon Parrington, Carl Becker, and Charles Beard, attempted to create a "usable history that would contribute directly to the solution of contemporary problems" (Cohen, 1976, 309).

17 Examples of such a prodromic, compilatory historiography are Richard G. Boone's Education in the United States (1889) and Edwin Grant Dexter's A History of Education in the United States (1904). 
As in the progressive philosophy of education, according to which the child's interests, socialization, and democratization replace any formal and discipline-centered methods, so subject-centered specialists in fields like history, philosophy, and the like, had to be replaced by the eclectic figure of a reconstructionist scholar, who had the 'social aim' as his own priority.

To do so, methods were extensively introduced in the practice of historiography that would raise harsh criticism later, as they were intended to select material from the past material inasmuch as it served the purpose of solving current social issues. In 1939, to mitigate such radical "abuses" of historiography, R. Freeman Butts, by then a historian of education at Teachers College, Columbia, warned historiographers, who adopted a "frankly critical, experimental, and progressive attitude", not to let this attitude interfere with the historian's ideal of objectivity: "pertinent and relevant materials should not be willfully overlooked or mutilated in order to fit what the writer would like to find" (Freeman Butts, 1939, vii).

This phase of the American historiography of education was bound to follow the dramatic fate of progressive education, which was rapidly dismissed in the 1950s and replaced on a large scale in the United States by different approaches. The figure of the historian-educationist was largely dismissed, criticized, and ridiculed so as to regain "professional reputation" for the historiography of education. Leading figures of the reaction against the "presentism" of their predecessors were Bernard Bailyn (born in 1922) and Lawrence Cremin (1925-1990) who, along with their attacks on the supposedly non-scientific attitudes of settlers in the field such as Cubberley and Monroe, also gave birth to the new history of education movement. The criticism of past historiographers, which Cohen labeled as partial and unfair to some extent (pp. 301-302), was epitomized by Cremin's The Wonderful World of Ellwood Patterson Cubberley (1965), a significant turning point for the self-perception of the American historians of education and the perception of their own mission. Pillars of such perception were a renewed relation to the field of general history and its methods, the rejection of any immediate repercussions on educational practices of the historical narrative, and the adoption of topics and instruments that belonged to social sciences, which echoed what the French school of the Annales had been doing until that moment. Bailyn's conception of a new history of education involved a broader concept of education than his predecessors', as he defined it "not only as a formal pedagogy but as the entire process by which a culture transmits itself across the generations [and] in its elaborate, intricate involvements with the rest of society" (Bailyn, 1960, p. 14). According to Cremin, those who failed-like Cubberley-to apply such a vision, committed four "cardinal sins against Clio": anachronism, parochialism, evangelism, and isolation from the mainstream of American historiography (Cremin, 1965, p. 43). To restore the academic credibility of the history of education, the new historians wanted to bridge such a gap, trying not to lose contact with the leaders in the field of professional education (Cohen, 1976, p. 323). ${ }^{19}$

Cohen summarized this new culture of historiography with a little emphasis, describing the appearance of new history after the "intellectual bankruptcy" of the socio-reconstructionists as a moment when "we were finally able to renounce the requirement that

19 Of course, such a reconnection was not merely ideal. Repairing the bridge meant basically attracting departmental historians to educational topics, reshaping learned societies such as the History of Education Society and journals such as the History of Education Journal (which was turned into History of Education Quarterly under the editorship of Ryland Crary in 1961). 
our work be immediately relevant and provide clear directions for dealing with current problems, dilemmas, and crises of contemporary education" (p. 325).

Cremin's trilogy American Education would be among the most important products of such an approach. His concept of education extended Bailyn's to include agencies beyond formal schooling, and the interactions between such agencies with American society at large. Such a complex concept of education-that in fact echoed much of the French historiographical debate-being so spread across social actors and factors, so distributed between formal and informal functions of societies, and so attentive to the long-lasting impact of social practices, dimensions, and mentalities-brought many to emphasize the disconnection between his new history method and concerns with presentism. Indeed, Cremin, and Bailyn too, did stress presentism as a bias of past historiography, and they certainly wanted to get rid of it to safeguard the seriousness of the historiographical work. Nonetheless, it would be unfair, if not a blatant mistake, to think that the dimension of the present was completely absent in the process of outlining the new history approach. Referring to Cremin's own words, Cohen limits the role of the "new" historian to providing insight and perspective, rather than ammunition, inspiration, or solutions to the practitioners of current education (p. 323). In this way, though, the relation between the present and history would be nothing more than a blurred re-edition of the ancient motto historia magistra vitae, which Cremin himself would correct. As he stated in a later interview, the history of education had a tighter relation to present concerns than this:

"Since I think history should be a lamp to light the present, I thought if I pursued a broader interpretation, I could be helpful to people thinking about educational policy today, because they would be able to canvass a broader range of institutions in looking for the solution to educational-policy problems" (Cremin, 1988).

Cremin's criticism of past presentism was made in the name of a different concept of the present, to which history had in any case to contribute. In the past, the historiographical category of education had been narrowed to formal schooling and teaching practices, while it involved a broader and complex interaction of social systems that - if properly understood - could and should benefit those very same educators who had been harmed and disoriented by the short cuts of a euphoric and simplistic historiography. This is why Cremin thought of his work as a strong form of "activism", for "I believe if I can provide this perspective-that combines a sense of the breadth, the complexity, the centrality of [education] in our experience, [...] that it would reinvigorate the debate over education" (Cremin, 1988).

Having its origins much like many of the educational approaches in the wake of the Russian win in the Cold War with the launch of Sputnik-and therefore as a product of very present concerns of American society-the new history did broaden, rather than cut off, the dimension of the present as the goal of historiography.

In the 1970s, though, a criticist approach to historiography made "disquieting" the liberal picture offered by new historians (Cohen, 1976, p. 326). Authors like Michael Katz (1971), Clarence Karier (1973 and 1975), Joel Spring (1972 and 1978), and Paul Violas (1978) revived and reinverted the presentism of the socio-reconstructionists by considering historiography as a form of social action. In their views, though, that optimistic vision that surrounded the socio-reconstructionist historiographers about the American school system was dropped in favor of an engaged and conflictual criticism that wanted 
to challenge the unjust or classist ideologies that permeated American public schools. Irony and polemic were brought back to serve as tools for a social-oriented and political historiography that was labeled as "radical revisionism", influenced as it was by categories drawn from French sociologists (such as Bordieau) and Marxism. They were interested in understanding the functions of control and social reproduction that harmed social mobility in the United States, the increasing professionalization of knowledge and discourse, the development of formal schooling for the masses and the role of the State in education.

New historians and radical revisionists inevitably clashed with each other, as their idea of serving the present through historiography was radically different. In Diane Ravitch, The Revisionist Revised: A Critique of the Radical Attack on the Schools (1978), the author renewed the old allegations that the new historians had launched against the reconstructionists, contesting with the revisionists the narrow scope of their concept of education, their determinist concept of classes and individual behavior, and a certain kind of enlightened bias according to which revealing the structure of an institution was enough to understand its social function (Nóvoa, 1997, p. 15). On the other side, Gene Grabiner accused Ravitch of conservativism and obscurantism (Grabiner, 1977), and David Tyack-although from a different perspective than that of Grabiner-seconded the revisionists' vision, saying that American urban schools, if they were not responsible for creating injustice in American society, surely played a role in perpetuating it (Tyack, 1974, p. 12).

The harshness of such a debate eventually faded away in the 1980 s and 1990s, when the field experienced the same explosion of topics and approaches that the success of postmodern paradigm brought about among the humanities and human sciences. American historians of education began to diversify their conceptual frameworks and methodological tools. The long-lasting inclination toward a socio-historical approach seemed unable to explain the complexity of change processes over a long timeframe, to apprehend the deep permanence and breaking points of school and educational dynamics (Nóvoa, 1997, p. 16). The postmodern lack of what François Lyotard called the legitimization provided by great narratives (grands récits) boosted the accumulation of studies and the multiplicity of themes, which resulted in a fragmented dispersion that could not be synthetized by any monistic perspective.

Nóvoa and Jablonka have both identified some tendencies in such a dispersion, that include an increasingly challenged socio-history of education due to the enlargement of the concept of historical time and a critique of the preferential use of quantitative approaches. Nóvoa, in particular, focused on five major ideal types of historiographic approaches: 1) an experiential and literary history that moved the attention from the structures of education to the subjects-in-education (especially those subjects that had not appeared in the previous historiography); 2) a renewed cultural history of education, which moved the attention from the externality of the educational processes to the internality of the schooling discourse; 3) a socio-intellectual history that rooted the old history of educational ideas into the historical context of their fortune, reception, and co-construction within the practices of formal and informal education; 4) a socio-political history that especially engaged facts regarding the historical organization of schools with educational policies and looked for their interactions with other social forms of organizing education and formation; and 5) a comparative history of education, in which-according to Nóvoa-a certain kind of primeval ressourcement resonates from the past of historiography (p. 72). 
To be sure, the American reception of the critical theory behind the developing of the historiography of education into such a variety of approaches had a great influence. What has been called the "postmodern turn" certainly had different flavors in countries like France or the United States. The ways through which works by the main figures of the School of Frankfurt were initially received, interpreted, and eventually overcome through the sophistication that a national cultural environment requires to understand its own structures and discourses, found in the United States an extremely fertile terrain to develop in scope and number. Race, gender, minorities, urban, linguistic, anthropological, cultural, and media studies contributed to an explosion of the field of the American historiography of education also thanks to the American way of approaching critical theory in the postmodern era. ${ }^{20}$

But this "way" was facilitated and in fact fueled by current and very present concerns that cut across American society and its specificity with respect to societies in the old continent; concerns that pertain to the subtle patterns of discourses through which social neglect, division, and inequalities have entered the practice of education across the layers of American formal and informal schooling. Through this very peculiar nature of American society, a home to and junction of cultures, migrations, social groups, and individual identities, the historiography of education took advantage of the postmodern fall of the leading meta-narrative to boost that "emancipatory" epistemology that was the American inculturation of the critical theory movement.

Such inculturation has been successful over time, and historiography is still very much influenced by it, as issues such as gender, race, minorities, underserved social groups, subjects-in-education with special needs, and many others have drawn the attention of historiographers that are moved by the current social tensions that cut across American society.

Despite the allegations of provincialism and parochialism that have often been raised against it, the American way of comparative historiography offered a different kind of "comparativism", and this is probably why such accusations often miss the point (an example of this is Silver, 1983, p. 180). In fact, an anthropological interest has been growing over time between the global interactions of social groups, traditions, and institutions that have been communicating on an inter-national scale, and a comparative perspective as a focus on national contexts and national state could not intercept it.

The phenomenon of globalization has done nothing but foster this anthropological vision, leading the American historiography of education to compare either systems and structures on a world scale or patterns of social constructs through in-depth specific surveys (Ginsburg, 1991; Boli and Ramirez, 1992; Meyer, Ramirez and Soysal, 1992; Ramirez and Ventresca, 1992; Meyer, Kamens and Benavot, 1992, Paulston, 1996; Lawn and Nóvoa, 2002, Meyer and Ramirez, 2010).

\section{Conclusions}

Three (Western) traditions in the historiography of education have developed over time toward comparative studies from very different epistemic backgrounds. Constrained as well as expanded by the dialectical tensions that have come to constitute its field of

20 Nóvoa exemplifies the inculturation of the broader European critical thought, including Foucault, Derrida, Barthes, Ricoeur, and Bourdieu among other by saying: "il faut être averti sur la façon dont certains auteurs européens ont été appropriés et relocalisés dans l'espace académique américain, en induisant une autre approche de leurs travaux et de leurs parcours intellectuels. Le Foucault américain est très différent du Foucault français" (Nóvoa, 1997, p. 72). 
research, the history of education has bounced between the quest for a distinctive, very specific identity with respect to its major disciplinary referents (history and education theory) and the epistemic liquidity of inter-disciplinarity. It has been the academic battlefield between general historians with an inclination toward the topic of education and educationists willing to pursue in the past the practical indications of teachers and educational practitioners. The gap between the two major lines of research, one on educational facts and the other focused on educational ideas, has seldom been unquestionably bridged. Socio-history and cultural history have appeared as different, sometimes conflicting, perspectives, and the geographical scope of historiography has wavered between nation states and local communities, often failing to have these dimensions in profitable dialogue with each other. Sometimes, the issue of the relation between present and past has overshadowed the fact that the first social responsibility of the historians of education is that of being good readers of their sources, and has provided convincing narratives that are intrinsically and scientifically bound, as Popper said, to be falsified. To be sure, the very same concept of "comparativism" to which the three traditions in the historiography of education we have mentioned have developed lately, has received different interpretations and its methods cover a wide and varied spectrum.

Still, globalization has had an undeniable impact on the ways that comparative studies should be done, especially as concerns the perspectives. In fact, categories such as nations and nation states have proved insufficient and misleading to give proper accounts about the social constructs that have been operated either before or since the very appearance of nation states in Europe. Furthermore, such categories overlook the social and cultural movements interacting on a global scale. Finally, a globalized perspective on the historiography of education reveals such categories as one of the many indicators of Eurocentric biases that have connoted historiography in terms of frameworks, concepts, timelines, and so on. When comparing school systems on an inter-national scale, the historiography of education has often applied criteria that belong to the constructs that have been developed in Europe, and tended to consign experiences and educational phenomena that did not fit such constructs to a pre-history of education, as if history could enter the scene only with the appearance of the Enlightened Europeans, these being either the colonists of the past that implanted their schools abroad, or the current historians implanting their social constructs in a past and place that do not fit them. An anthropologically post-enlightened, global comparative historiography of education will be likely the next epistemological step that is required to face the needs of a planetary age.

\section{References}

Alamercery, V. (2008), "L'historiographie française de l'éducation. Essai de cartographie de ses objets et de ses auteurs", Histoire de l'éducation, 117, 97-116.

Anderson, M. L. (2000). Practicing Democracy: Elections and Political Culture in Imperial Germany, Princeton: Princeton University Press.

Bailyn, B. (1960), Education in the Forming of American Society: Needs and Opportunities for Study. Chapel Hill: University of North Carolina Press. 
Barrau, T. (1857). De l'histoire de l'enseignement et de l'éducation. In Manuel general de l’instruction primaire (4-5), 3e série, vol. 1.

Bellatalla, L. (2005). La storia della pedagogia tra dimensione concettuale e modello educativo. In L. Bellatalla (Ed.), La Scienza dell'educazione: il nodo della storia (32-38). Milano: FrancoAngeli.

Berg, C. (Ed.). (1987-91). Handbuch der deutschen Bildungsgeschichte. München: Beck (6 voll).

Biedermann, J. G. (1752-54). Altes und Neues von Schulsachen. Halle: Gebauern.

Boli, J. and Ramirez, F. (1992). Compulsory Schooling in the Western Cultural Context. In R. Arnove, P. Altbach and G. Kelly (Eds.), Emergent Issues in Education: Comparative Perspectives (25-38). Albany: Suny Press.

Burnham, W. H. and Suzallo, H. (1908). History of Education as a Professional Subject. New York: Columbia University.

Cambi, F. (2005). Modelli di storiografia dell'educazione. In La storiografia dell'educazione. Metodi, fonti, modelli e contenuti (85-93). Milano: FrancoAngeli.

Caspard, P. (1979). La recherche en histoire de l'éducation: résultats d'une enquête. Histoire de l'éducation, 2-3, 5-17.

- (1984). L'histoire de l'éducation en France: remarques sur la dynamique sociale d'un champ disciplinaire. Full infurmatiu, 3, 5-23.

- (1988). Histoire et historiens de l'éducation en France. Les Dossiers de l'éducation, 14-15.

- (1998). L'éducation, son histoire et l'État. L'exemple français. Annali di storia dell'educazione, 5, 101-123.

- (2000). Vingt année d'Histoire de l'éducation. Histoire de l'éducation, 85, 73-87.

Caspard, P. and Caplat, G. (1981). Afterword to A. Prost, L'Histoire génerale de l'éducation et de l'enseignement en France (665-676). Paris: Nouvelle Libraire de France, 4.

Caspard P. and Rogers, R. (2012). The history of education in France: a laboriously useless education? In J. E. Larsen (Ed.), Knowledge, Politics and the History of Education (73-85). LIT: Berlin.

Cohen, S. (1976). The History of the History of American Education, 1900-1976: The Uses of the Past, Harvard Educational Review, 46(3), 298-330.

Compère, M. M. (1995). L'histoire de l'e' ducation en Europe : essai comparatif sur la façon dont elle s'é crit. Paris: Institut National de Recherche Pédagogique.

Cremin, L. A. (1965). The Wonderful World of Ellwood Patterson Cubberley: An Essay on the Historiography of American Education. New York: Bureau of Publication Teachers College.

- (1988). History: 'A Lamp to Light the Present', Education Week (March 16). 
Cubberley, E. (1947). Author's Preface. In Public Education in the United States: A Study and Interpretation of American Educational History, revised and enlarged edition. Boston: Houghton Mifflin Company.

Depaepe, M. (2010). The Ten Commandments of Good Practices in History of Education Research. Zeitschrift für Pädagogische Historiographie, 16(1), 31-49.

Depkat, V. (2009). The Cultural Turn in German and American Historiography. Amerikastudien/American Studies, 54(3), 425-450.

Dunkel, H. B. (1970). Herbart and Herbartianism: An Educational Ghost Story. Chicago: University of Chicago Press.

Durkheim, E. (1969). The Evolution of Educational Thought. Lectures on the formation and development of secondary education in France. Trans. Peter Collins, $2^{\text {nd }}$ ed. London, Henley \& Boston: Routledge and Kegan Paul.

Eigenmann, P. (2017). Voraussetzungen und Folgen der Institutionalisierung interkultureller Pädagogik in den 1980er-Jahren. Jahrbuch für historische Bildungsforschung, 23, 1-23.

Elgin, C. Z. (1999). Epistemology's Ends, Pedagogy's Prospects. Facta Philosophica, 1, 39-54.

English A. R. (2013). Discontinuity in Learning: Dewey, Herbart and Education as Transformation. New York: Cambridge University Press.

Fend, H. (2007). Geschichte des Bildungswesens: der Sonderweg im europäischen Kulturraum. Wiesbaden: VS Verlag.

Fuchs, M. (2013). Pädagogik und die Moderne: Studien zur Kulturellen Grundlagen der Erziehungswissenschaft. München: Utz Verlag.

Garmo (de), C. (2016). Herbart and the Herbartians. Kijv: Leopold Classic.

Ginsburg, M. B. (Ed.). (1991). Understanding Educational Reform in Global Context: Economy, Ideology and the State. New York and London: Routledge.

Gogolin, I. (2002). Interkulturelle Bildungsforschung. In R. Tippelt and B. Schmidt (Eds.), Handbuch Bildungsforschung (297-316). Wiesbaden: VS Verlag.

Grabiner, G. (1977), In Defense of Revisionism. Paper presented to the Annual Meeting of the American Educational Research (New York, April 3-8 1977) under the title The Limits of Educational Revisionism, https://files.eric.ed.gov/fulltext/ED141254. pdf.

Granese, A., (2008). La Conversazione Educativa. Roma: Armando Editore.

Groppe, C. (2012). History of Education in Germany: Historic Development - Results - Raison d'être. In J. E. Larsen (Ed.), Knowledge, Politics and the History of Education (179-194). Berlin: LIT.

Guex, F. (1892). Le P. Girard, élève de J. F. Herbart. Lausanne: Viret-Genton. 
Herbart, J. F. (1806). Allgemeine Pädagogik aus dem Zweck der Erziehung abgeleitet. Göttingen, Röwer.

Howard, T. A. (2006). Protestant Theology and the Making of the Modern University. New York: Oxford University Press.

Hull, I. (1996). Sexuality, State, and Civil Society in Germany, 170o-1815. Ithaca: Cornell University Press.

Julia, D. and Revel, J. (Eds.). (1986-89). Les universités européennes du 16. Au 18. siècle: Histoire sociale des populations étudiantes. Paris: Éditions de l'École des hautes études en sciences sociales.

Julia, D., Bonin, S. and Langlois, C. (Eds.). (1987). Atlas de la Révolution Française: L'enseignement 1760-1815. Paris: Éditions de l'École des hautes études en sciences sociales.

Karier, C. J. (1975). Shaping the American Educational State 1900 to the Present. New York and London: Macmillan.

Katz, M. B. (1971). School Reform: Past and Present. Boston: Little Brown and Co.

- (1971). The Present Moment in Educational Reform. Harvard Educational Review, 41(3), 342-359

Katz, M. B., Karier, C. J., Spring, J. and Violas, P. (1973). Roots of Crisis: American Education in the Twentieth Century. Chicago: Rand McNally.

Kehrbach, K. (s.d., ca. 1886). Kurzgefasster Plan der Monumenta Germaniae Paedagogica. Berlin: A. Hoffmann \& C.

Kemplerer, V. (2006). The Language of the Third Reich: A Philologist's Notebook. London and New York: Continuum.

Kliebard, H. M. (1999). Dewey and Herbartians: The Genesis of a Theory of Curriculum. Counterpoints, 70, 68-81.

Koselleck, R. (1972). Einleitung. In O. Brunner, W. Conzer and R. Koselleck (Ed.), Geschichtliche Grundbegriffe: Historisches Lexikon zur politisch-sozialen Sprache in Deutschland, $1(A-D)$. Stuttgart: Ernst Klett Verlag.

Kotzee, B. (Ed.). (2014). Education and the Growth of Knowledge: Perspectives from Social and Virtue Epistemology. Malden: Wiley \& Sons.

Krüger-Portraz, M. (2005). Interkulturelle Bildung: Eine Einführung. Münster and New York: Waxmann Verlag.

Keuffel, G. G. (1743). Historia originis ac progressus scholarum inter Christianos. Helmst: Weygand.

Lawn. M., Nóvoa, A. (2002). Fabricating Europe: the formation of an education space, London, Kluwer, 2002. 
Le Cam, J. L. (2013). L'histoire de l'éducation: discipline de recherché historique ou science auxiliaire de l'action pédagogique? Les leçons d'une comparaison francoallemande. Histoire de l'éducation, 92-123.

Liebau, E., Miller-Kipp, G. and Wulf, C. (Eds.). (1999). Transformationen der Zeit. Weinham, Deutscher Studien Verlag.

Lüdtke, A. (1991). Herrschaft als soziale Praxis: historische und sozial-anthropologische Studien. Göttingen: Vandenhoeck und Ruprecht.

McNeely, I. F. (1993). The Emancipation of Writing: German Civil Society in the Making, 1790s-1820s. Berkeley: University of California Press.

Medick, H. (1996). Weben und Überleben in Laichingen, 1650-190o: Lokalgeschichte als Allgemeine Geschichte. Göttingen: Vandenhoeck und Ruprecht.

Meyer, J. W., Kamens, D. H. and Benavot, A. (1992). School Knowledge for the Masses: World Models and National Primary Curricular in the Twentieth Century. London: Falmer Press.

Meyer, J. W., Ramirez, F. and Soysal, Y. (1992). World expansion of Mass Education, 1870/1980. Sociology of Education, 65(2), 128-149.

Meyer, J. W., Ramirez, F. O. (2010). La educación en la sociedad mundial: teoría institucional y agenda de investigación de los sistemas educativos. Barcelona: Ediciones Octaedro.

Nóvoa, A. (1997). La nouvelle histoire américaine de l'éducation, Histoire de l’éducation, $73,3-47$.

Oelkers, J. (1999). Die Geschichte der Pädagogik und ihre Probleme. Zeitschrift für Pädagogik, 45(4), 461-483.

Paulston, R. G. (Ed.). (1996). Social Cartography: Mapping Ways of Seeing Social and Educational Change. New York: Garland.

Penny, H. G. (2008). The Fate of Nineteenth Century in German Historiography. The Journal of Modern History, 8o(1), 81-108.

Ramirez, F. O., and Ventresca, M. J. (1992). Building the Institution of Mass Schooling: Isomorphism in the Modern World. In B. Fuller and R. Robinson (Ed.), The Political Construction of Education: The State, School Expansion, and Economic Change (47-59). New York: Praeger.

Ringer, F. K. (1969). The Decline of the German Mandarins: The German Academic Community, 1890-1933. Cambridge: Harvard University Press.

- (1979). Education and Society in Moder Europe. Bloomington, Indiana University Press.

- (1992). Fields of Knowledge: French Academic Culture in Comparative Perspective, 1890-1920. Cambridge: Cambridge University Press. 
Ruhkopfs, F. E. (1794). Geschichte des Schul- und Erziehungswesens in Deutschland. Bremen: Wilmans.

Schöttgen, C.(1717).Diatribehistorico-litterariade statuscholarumantereformationem. Frankfurt: Konrad.

Schmitt, F. (2005). What are the Aims of Education? Episteme, 1(3), 223-234.

Siegel, H. (2004). Epistemology and Education: An Incomplete Guide to the SocialEpistemological Issues. Episteme, 1, 129-137;

Siegel, H. (2017). Education's Epistemology: Rationality, Diversity, and Critical Thinking. New York: Oxford University Press.

Silver, H. (1983). The Uses of Parochialism: Comparative and Cross Cultural Study. In J. H. Best (Ed.), Historical Inquiry in Education: A Research Agenda. Washington: The American Educational Research Association.

Spring, J. H., (1970). Education as a Form of Social Control. Cuernavaca: Centro Intercultural de Documentación.

- (1972). Education and the Rise of the Corporate State. Boston: Beacon Press.

- (1978). American Education: An Introduction to Social and Political Aspects. New York: Longman.

Tröhler, D. (2006). Lehrerbildung, Nation und pädagogische Historiographie. Die 'Geschichten der Pädagogik' in Frankreich und Deutschland nach 1871. Zeitschrift für Pädagogik, 52(4), 540-554.

Tyack, D. (1974), The One Best System: A History of American Urban Education. Cambridge: Harvard University Press.

Violas, P. (1978). The Training of the Urban Working Class: A History of Twentieth Century American Education. Chicago: Rand McNally.

Watson, L. (2016). The Epistemology of Education. Philosophy Compass, 11(3), 146-159.

Wulf, C. (Ed.). (1996). Anthropologisches Denken in der Pädagogik 1750-1850. Weinheim: Deutscher Studien Verlag.

Zelić, T. (2018). Bildung and the historical and genealogical critique of contemporary culture: Wilhelm von Humboldt's neo-humanistic theory of Bildung and Nietzsche's critique of neo-humanistic ideas in classical philology and education. Educational Philosophy and Theory, 5o(6-7), 662-671. 